\title{
The Harmonization of Naqlī And 'Aqlī Approaches In Affirming The Islamic Creed In Dāwūd Al-Fațān̄̄'s Ward Al-Zawāhir
}

\author{
Hasbullah bin Mohamad*
}

\begin{abstract}
This paper offers an examination of the scholarship of Dāwīd al-Fațāni in dealing with the revealed sources (naqlī) and qualified scholarship in the exercise of the intellect ('aqli) in affirming the Islamic creed. The author emphasizes the determination of Dāwüd al-Fațāni on the need to refer to the authority of naqlī and 'aqli so as to guard against deviation and exceeding the proper limits of methodological practices towards theological goal of knowing God (ma'rifat Allāh). A qualitative methodology in which the textual analysis and comparative study was employed to analyse textual materials related to Dāwūd al-Fațānī especially his writing, the Ward al-Zawähir. Findings indicate that Dāwūd al-Fațānì attempted to integrate the naqli and 'aqlì approaches, and harmonize such distinctions in dealing with theological approaches especially that of Salaf and Khalaf's.
\end{abstract}

Keywords: Naqlī, 'Aqlī, Hadīth, Dāwūd al-Fațānī, Sunnism.

\section{Introduction}

Shaykh Dāwūd bin 'Abd Allāh al-Fatān̄̄̄1 (d. 1263 H/1847 CE) is one of the most influential and prolific Malay scholars of the nineteenth century whose treatises are considered among the most important works of the Islamic sciences in the Malay Archipelago. He has written substantially in diverse disciplines yet his main contributions are in the Islamic creed, Islamic jurisprudence, and Sufism. He authored at least sixty-nine books and treatises of which the most well-known are Munyat al-Muṣallī $(1242 \mathrm{H})$, Furū' al-Masā'il $(1257 \mathrm{H})$, al-Durr al-Thamīn $(1232 \mathrm{H})$, Minhāj al- 'Ābidīn $(1240 \mathrm{H})$, and Sullam al-Mubtadī $(1252 \mathrm{H}){ }^{2}$

\footnotetext{
* Dr. Hasbullah bin Mohamad, is Assistant Professor, Kulliyyah of Islamic Revealed Knowledge and Human Sciences,International Islamic University Malaysia, Kuantan Campus. Email: asbul74@iium.edu.my

${ }^{1}$ Shaykh Dāwūd bin 'Abd Allāh al-Fațānī is later referred to as Dāwūd al-Fațānī

${ }^{2}$ Francis R. Bradley, "Syeikh Daud bin Abdullah al-Fatān̄̄̄s writings contained in the National Library of Malaysia," Jurnal Filologi Melayu, vol. 15 (2007): 121; Wan
} 
Al-Durr al-Thamin, which was completed in $1232 \mathrm{H}$, is a theological work which is still widely used in traditional schools (pondok) and mosques today. However, the most significant work on Islamic creed is Ward al-Zawāhir li hall alfāz 'Iqd al-Jawāhir ('ilm al-Tawhīd Ahl alSunnah wa al-Jamā'ah) (1245 H). ${ }^{1}$ In fact, Ward al-Zawāhir deals with the authority of the naqli and 'aqli approaches in the sense of complementary being in order to eliminate blind imitation (taqlìd) towards knowing God (ma 'rifat Allāh). Dāwūd al-Fațānī was consistent with his attitude of middle course in dealing with different schools of thought based on such authority in the sense the revelation is superior to the intellect and never contradictory. Thus, his attempt to harmonize the dispute of the theological issues demonstrates his treatment of the use of the naqli and 'aqli in approaching the Islamic creed is strongly significant.

\section{Dāwūd al-Fațānī's Attitude towards Naqlī and 'Aqlī}

Dāwūd al-Fațānī signified the optimal use of the revealed sources (naqlī ) indicating that the proofs must come from reliable sources. In this respect, he explicitly applied stringent conditions for the naqli where he strictly accepted only the authentic (sahihh) and fair (hasan) hadith, while the weak hadith ( $\left.d a a^{i} f\right)$ is applicable in the branches of religious practices $(f u r \bar{u})$ and the merit of certain deeds (fadā'il al-a' $m \bar{a} l)$. He stated:

The sam iyyah (naqlī) consists of the proofs that come from the Qur'ān, Sunnah that is authentic (sahīh) or fair (hasan), and consensus (ijm $\bar{a}$ ) are applicable in the Islamic creed. In contrast, the weak hadīth ( $\left(a^{\prime} \bar{l} f\right)$ and analogy (qiyās) which are only applicable for practical means of the branches (fur $\bar{u}$. 'amaliyyah) except those of very weak hadith due to the chains of transmissions (isnād or turuq) of the liars ( $k \bar{a} d h i b)$ or supposed liars (ittihām bi al-kādhib. The role of qiyās concerning the practical of the branches goes as the ijm $\bar{a}{ }^{\prime}{ }^{2}$

Dāwūd al-Fațānī's methodology of the authority of the Hadìth

\footnotetext{
Mohd Shaghir bin Abdullah, "Pengarang manuskrip kitab di Alam Melayu: suatu tinjauan awal," Jurnal Filologi Melayu, vol. 3 (1994): 87.

${ }^{1}$ Dāwūd bin 'Abd Allāh al-Fațānī, Ward al-Zawāhir li hall alfāz 'Iqd al-Jawāhir ('ilm al-Tawhīd Ahl al-Sunnah wa al-Jamā'ah), edited by Wan Mohd Shaghir bin Abdullah, (Kuala Lumpur: Khazānat al-Fațāniyyah, 2000). The work is later referred to as Ward al-Zawāhir.

${ }^{2}$ Dāwūd al-Fațānī, Ward al-Zawāhir, 63.
} 
clearly shows that it must come from the authentic (Sahīh) and fair (hasan) Hadìth along with the consensus (ijmā'). In this respect, his methodology of the authority of the Hadīth -i.e. the șahih and hasan-of the solitary hadith ( $a h \bar{a} d)$ seems consistent with the methodology of hadīth scholars (muhaddithün) of the Ahl al-Sunnah. ${ }^{1}$ Likewise, the authority of the recurrent hadith (mutawätir), which is accepted without critical evaluation of the chains of transmitters (isnād) due to the large numbers of transmitters of all levels of the isna $\bar{d}$, constitute undisputable authority. Otherwise, the Mu'tazilite's attitude towards hadìth ahād totally differs abjectly from Ahl al-Sunnah in that they reject hadith $a h \bar{a} d$ in matters of theology, and accepting only the mutawatir ones. ${ }^{2}$

Dāwūd al-Fațānī's view is in line with that of the majority of scholars (jumhūr) of the Ahl al-Sunnah who accept the Hadith ahād in argument of theology, in which its usage is extensive because most of the ahādith come in this form compared to the mutawātir. ${ }^{3}$

Dāwūd al-Fatān̄̄'s methodology of ahāàith indicates that the weak hadith ( $\left.d a a^{i} i f\right)$ is applicable in the branches of religious practices ( $f u r \bar{u}$ ) and the merit of certain deeds (fad̄'il al-a'māl) as well as religious advice (al-wa'z). His Ward al-Zawāhir consistently indicated that hadith da iff could be applied provided it is not the one categorized as very weak hadìth from unreliable or liar transmitters (isnād kädhib), or supposed liars (matrūk), or dishonour (munkar). ${ }^{4}$

Based on his attitude towards hadīth ḍ 'îf, Dāwūd al-Fațānī, like the fuqahà', employed hadìth da 'îf within its limitation, with priority on the authority of the hadith Sahìh, and hasan. In this respect, he is consistent with his methodology on theological issues in dealing with the hadìth da îf, even signifying that it is more reliable compared to the other words and views, which seem more likely to follow Abū Dāwūd (d.899 CE) and Aḥmad Ibn Hanbal's (d. 855 CE) view. ${ }^{5}$ His Jam 'alFawā'id said:

Some pious (șâlihinn) said: I have seen (in my dream) the Prophet

\footnotetext{
${ }^{1}$ Muḥammad 'Ajāj al-Khațīb, Ușūl al-Hadīth, (Bayrūt: Dār al-Fikr, 1981), 302.

2 Jamāl al-Dīn Ibn Muḥammad Sa'īd al-Qāsimī,, Qawā'id al-taḥdìth min funūn muștalah al-ḥadīth, (Bayrūt: Dār al-Kutub al-'Ilmiyyah, 1979), 148.

${ }^{3}$ Ibn Hajar al-'Asqalān̄̄, Aḥmad ibn 'Alī ibn Muhammad, al-Nukat 'alā nuzhat alnazar fì tawḍ̄h Nukhbat al-Fikar, (al-Riyāḍ: Dār Ibn Jawzī, 2003), 61-62.

${ }^{4}$ Dāwūd al-Fațānī, Ward al-Zawāhir, 63.

5 Jalāl al-Dīn 'Abd al-Raḥmān ibn Abū Bakr al-Suyūṭ̂̄, Tadrīb al-Rāwī fì sharh Taqrīb al-Nawawī, (al-Madīnah: Maktabat al-'Ilmiyyah, 1972), vol. 1, 299.
} 
(P.B.U.H) beside the Ka'bah, so I said: "O Messenger you have said: "Whoever listens to my tradition, I promise him with a reward and when he practices it desiring the reward he would be rewarded." Although the hadith is weak. ${ }^{1}$

Dāwūd al-Fațānī’s attempt to employ the hadīth da'îf concerning the branches of religious practices ( fur $\bar{u})$ and the merit of certain deeds (fadā'il al-a'māl) in his works to get closer to Allah (for reward and pleasure) is evidently significant. He asserted that Hadith da'îf greatly contributes towards knowing God (ma'rifat Allāh) that may be achieved through the Islamic activism -to approach God (taqarrub)- especially that of virtuous deeds and fadā'il al-a 'māl as long as it does not contradict with the fundamental principles of the shar: For that, his Ward al-Zawähir employed the use of hadìth da'iff altogether with the Qur'anic verses and the authorized aÍäiith. In fact, he consistently considered that the use of hadith da if is to support the Qur'anic verses as well as the authentic hadith.

Dāwūd al-Fațānī's criticism of the hadìth da 'îf clearly demonstrates his consistent methodology concerning the authority of hadīth. In fact, he sometimes distinguished the authentic ahādith from the $d a$ 'if ones. For instance, he refused to accept the transmissions of

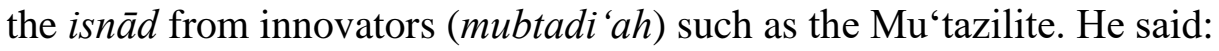

The Mu'tazilite asserts the role of Izrā'īl (Angel of Death) who only takes the soul of al-thaqalayn (i.e. people and jinn). This opinion is not valid when it refers to the hadith ( $d a$ if $f$ ) reported by Abū al-Shaykh, al-'Uqaylī, and al-Daylamī of Anas that (said): "The death of animals (bahä'im) and creatures on earth such as insects (in the jungle), harvest mite, dog lice, locusts, animals such as cattle and others (their souls) will be taken away by God instead of malak al-mawt (Izrā'īl). This would happen after they glorified (tasbīh) Him." In fact, the above hadith is weak ( $d a$ i $i f) . .{ }^{2}$

Dāwūd al-Fațānī's Ward al-Zawāhir treated the authority of the hadīth da'iff either through his justifications (critics) of the chains of transmitters $(i s n \bar{a} d)$ or through transmission of the hadith. Regarding hadìth da 'îf , he found justification as follows:

\footnotetext{
${ }^{1}$ Dāwūd al-Fațānī, Jam 'al-Fawā' 'id, 168.

${ }^{2}$ Ibid., 254.
} 
Among Allah's Blessing (to His servants) in resurrection day, $\mathrm{He}$ would reward the pious people according their deeds, which differs (tafāwut) one another, as quoted from the weak hadìth ( $\left(a^{\prime}{ }^{\prime} f\right)$ : "Those who recite "subhānallāh" will be rewarded for it a hundred thousand times (rewards) and he will be rewarded based on the deeds by God."1

Based on Dāwūd al-Fațānī's treatment of the authority, it may derived that the sahih and hasan are accepted along with the use of hadith da îf which is to support either the stronger or similar ones. He strongly emphasized the authority of the revealed sources. Thus, he clearly retained his methodology in dealing with the use of the naqli especially the authority of hadith on his deliberation of theology in Ward al-Zawāhir. However, further detailed studies are required to arrive at a definite assessment of his consistency on his approaches to theology regarding the use of naqli in Ward al-Zawāhir.

Regarding his attitude towards 'aqlī, Dāwūd al-Fatānī asserted that his theological methodology concerning 'aqli is to follow al-Ash'arī in demonstrating a significant role to intellect ( 'aql) especially in kaläm. In Ward al-Zawāhir, he consistently applied such methodology with regard to his indirect response to the religious milieu in Mecca as well as in the Malay Archipelago.

Dāwūd al-Fațānī's approach on theology is obviously in line with al-Ash'arī and al-Ghazālī (Ash'arite) who took the middle course with sufficient use of the revealed sources (naqlī) as well as intellect ('aqlī) in dealing with the traditionalists and rationalists. Al-Ash'arī's approach follows Ibn Hanbal's methodology in glorifying the use of the naqli after he left the Mu'tazilites, whose approach transgresses to glorify the 'aqlī as a measurement of the human actions either good or bad (alhasan wa al-qabh). Nevertheless, at the same time, he did not deny the role of the 'aqli as of the mutakallimūn of the Ahl al-Sunnah. ${ }^{2}$

Dāwūd al-Fatān̄ī emphasis on the use of 'aqlī's approach in Ward al-Zawāhir is significant as he referred to the opinions of leading Ash'arite scholars such as al-Bāqillānī (d.1013), al-Isfiraynī (d.1027), alBaghdādī (d.1071), Imām al-Ḥaramayn al-Juwaynī (d.1085), al-Ghazālī

\footnotetext{
${ }^{1}$ Ibid., 305.

${ }^{2}$ George Makdisi, “Ash'arī and the Ash'arites in Islamic Religious History,” in Islamic philosophy and theology, edited by Ian Richard Netton, (New York: Routledge, 2007), vol. 2, 356, 280 .
} 
(d.1111), al-Shahrastānī (d.1153), al-Rāzī (d.1210), al-Subkī (d.1370), al-Sanūsī (d.1490), and al-Laqqānī (d.1631). In respect of Ward alZawāhir commentary, he referred to al-Laqqānī's Jawharat al-Tawhīd and its commentaries on works. These sources obviously indicate his connection with the mainstream Ash'arite's dealing with 'aqlī. In fact, his attempt to attach the views of Jawharī al-Bukhārī's kalām in his Ward al-Zawāhir illustrates his treatment of kalām in his writings. ${ }^{1}$

However, despite being in line with the Ash'arite's approaches, Dāwūd al-Fațān̄ was not only rigid with certain sectarian school of thought stands but rather employed other relevant approaches towards the theological goal of ma 'rifat Alläh. He accepted the Salaf along with Khalaf approaches in dealing with naqli and 'aqli in the light of harmonization and integration (tawfiq) approaches particularly in dealing with the dispute of anthropomorphism (tashbih $).^{2}$ This attempt is not strange to Dāwūd al-Fațānī since he used to the exposure to the religious doctrinal climate in Hijāz, especially the polemics between Wahhabism and Sufism. Additionally, his broad exposure to al-Ghazālī's works, whose thought employs the middle course accepting both; the approaches of the Salaf and Khalaf which were illustrated in al-Iqtișād fi al-I'tiqād and Iljām al- 'Awwām, has influenced his stand on theology towards Salaf and Khalaf. Al-Ghazālī sometimes accepted the employment of kalām as portrayed in his al-Iqtișād fi al-I'tiqād and in other times was inclined to the Salaf with the emphasis on naqli to elevate from blind imitation (taqlīd) to certitude (yaqin). In this regard, al-Ghazālī stated:

Kalām was not sufficient in my case, nor was it a remedy for the malady of which I was complaining. To be sure, when the discipline of kalām acquired some status and had been engaged in for some length of time, the mutakallimūn showed an earnest desire for attempting to defend orthodoxy through study of the true natures of things. They plunged into the study of substances and accidents and their principles. But since that was the aim of their own science, their discussion on the subject was not the aim of their own science, their discussion on the subject was not thoroughgoing; therefore it did not provide an effective means of dispelling entirely the darkness due to the bewilderment about the

\footnotetext{
1 Abdul Rahman bin Haji Abdullah, Pemikiran umat Islam di Nusantara, (Kuala Lumpur: Dean Bahasa dan Pustaka, 1990),106-107.

${ }^{2}$ Dāwūd al-Fațānī, Ward al-Zawāhir, 65-66.
} 
differences dividing man. ${ }^{1}$

Al-Ghazāli preferred the approach of the Salaf on their use of naqli prior to 'aqlī, which is more accurate with Allah's injunction without neglecting the role of reason in Islamic creed. However, his priority inclined to the science of unveiling (kashf) of Sufism (tașawwuf), which is, according to him, approachable in knowing God. He explained:

From the very beginning of the way of unveiling divine mysteries (al-mukāshafah) and visions (al-mushāhadah), even when awakened, the Sufis see angels and spirits of the prophets and hear voices coming from them and learn useful things from them. Then their "state" ascends from the vision of forms and likenesses to stages beyond the narrow range or words: so if anyone tries to express them, his word contains evident errors against which he cannot guard himself. ${ }^{2}$

In this respect, Dāwūd al-Fațānī's and al-Ghazālī 's treatment of kalām and Sufism (kashf) are significant, but his attempts demonstrated the complementary use of both vis-a-vis ma'rifat Alläh rather than alGhazālì's kashf. His 'aqli approaches could be observed in his usage of kalām and intellectual authority of the consensus (ijm $\bar{a})$, analogy (qiyās), Qur'anic interpretation based opinion (tafsir bi al-ra'y) including ta'wīl and ijtihād along with the use of naqli, which was in line with al-Ash'arī's Istihsā̄n al-khawd fì 'Ilm al-Kalām and al-Luma ‘3 Both naqli and 'aqli are capable of eliminating blind imitation (taqlīd) to certainty (tahqiq ) regardless of the distinctions between the scholars and even between the Salaf and Khalaf. Instead, he attempted to harmonize and integrate such distinctions. As such, his approach distinguishes Ward al-Zawāhir from other classical jawi treatises. He stated:

Al-Ash'arī (leader of Ahl al-Sunnah) asserts that the ma 'rifat is achieved through the mandatory use of shar' (i.e. revelation), which provides certainty (tahqiq $)$ towards it, instead of the

\footnotetext{
${ }^{1}$ Abū Hāāmid Muḥammad al-Ghazālī, al-Munqidh min al-ḍalāl. (Dimashq: Dār alHikmah, 1994), 49.

${ }^{2}$ Ibid. 84.

${ }^{3}$ Abū al-Ḥasan al-Ash'arī, Istiḥsān al-khawd fì 'Ilm al-Kalām, 91; Abū al-Ḥasan alAsh'arī, al-Luma', (Bayrūt: Dār al-Kutub al-'Ilmiyyah, 2000), 85.
} 
intellect ('aql)). Nevertheless, nazar (using the intellect) also leads to ma'rifat. Therefore, nazar is mandatory as long as it serves the attainment of ma'rifat which is obligatory on every mukallaf. ${ }^{1}$

Based on Dāwūd al-Fațānī's approach above, his treatment of naqlī was significant in the sense that reputable scholars deserve to deal with intellect towards ma'rifat Allāh regardless of their school of thought sentiments. These efforts would support to achieve the objective of strengthening the Islamic creed.

\section{Ward Al-Zawāhir's Harmonization in Dealing with The Naqlī And 'Aqlī}

Dāwūd al-Fatānī's approaches on theology to affirm the Islamic creed in his jawi treatise as reflected in Ward al-Zawāhir could be observed in his attempt to utilize the optimal use of the authority of the naqū and ' $a q \bar{\imath}$ argument. Interestingly, he dealt with both in the sense of complementary manner based on its authority and either way, it is supposed to harmonize such a dispute in a proper manner. In dealing with the harmonization of the theological arguments, Dāwūd al-Fațānì's Ward al-Zawāhir justified its usage based on authority and relevancy case by case.

\section{The Preference (Tarjīh) between Ta'wīl and Tafwìd}

Dāwūd al-Fațānī's harmonization between the different views of scholars is among his approaches on theology as long as it comes from the authority regardless of school of thought sentiments. In respect of anthropomorphism, he sought to harmonize between the literal understanding without its modality (tafwi $\bar{c}$ ) of the Salaf and the interpretive (figurative) way ( $\left.t a^{\prime} w \bar{l} l\right)$ of the Khalaf pertaining to the disputes of the anthropomorphic verses (mutashābihāt). For him, both have authority to do their own interpretation ( $t a$ 'wil or tafwìd) based on authoritative arguments, which are attainable towards the theological goal of knowing God (ma'rifat Allāh). Sometimes he inclined to the

\footnotetext{
${ }^{1}$ Dāwūd al-Fațān̄̄, Ward al-Zawāhir, 19.
} 
Khalaf's ta'wìl, which is relevant particularly to ignorant people, innovators, and unbelievers, justifying that tafwi $\bar{c}$ causes misunderstanding, and $t a$ 'wīl would provide proper understanding and avoid confusion. He stated:

The preference (tarji h) of the scholars (people) for the Khalaf with the figurative way $\left(t a{ }^{\prime} w \bar{l} l\right)$ over tafwìd (i.e. accept the revealed text without interpreting its modality) is because of some factors. This justifies if tafwi d is sufficient to the rights of a religious people ('âlim), but it is insufficient neither for the ignorant layman (' $\bar{a} m \vec{\imath})$ nor those of the innovators (mubtadi'ah), nor the disbeliever and those who practice blind imitation (taqlid $)$. For those who accept the sacred verses with its modality of anthropomorphic verses (tajsìm), the tafwì them, which is against the Qur'ān, Allah says: "Here is a plain statement to men, a guidance and instruction to those who fear Allah," and "O mankind! There has now come unto you an admonition from your Sustainer, and a cure for all (the ill) that may be in men's hearts," and "Now there has come unto you from God a light, and a clear divine writ."

Regarding the above, his Ward al-Zawāhir's approach was in line with the view of the use of authority of the naqli and 'aqli arguments in serving the arguments on theology regardless of the school of thought sentiments, seen in how he preferred (tarjīh) the Khalaf, and also the Salaf, based on its relevance. Thus, his attempt indicates that the aqli argument would serve to be in line with the true understanding of authorized revealed sources (naqlī ). Dāwūd al-Fațānī like the Ash'arite (Khalaf) attempted to ta'wīl the mutashābihāt to avoid confusion, but he also did not deny the need to tafwìd, so that it does not deviate from the real meaning intended by Allah as required by the Salaf. For instance, he sometimes justified the relevance of the tafwìd as he said:

The Salaf is preferred (räjih) and stronger because ta'wīl needs more knowledge and wisdom in order to facilitate ta'wīl in line with the text (naqli) and its meaning. Those amongst them are the scholars (a'immah) of the four sects (madhāhib al-arba'ah). Such methodology (tafwīi) is more genuine (peaceful) because

\footnotetext{
${ }^{1}$ Ibid., 64.
} 
we are afraid that we determined the meaning, which is not intended by Allah. ${ }^{1}$

In this regard, it clearly shows that his attitude to the anthropomorphism (tashbīh) was accepting both $t a$ 'wìl and tafwì $d$ based on its relevance and the ability of the individuals who deal with it. Thus, his approach on theology seems not rigid to the Ash'arite alone, instead his harmonization and integration between the dispute of the Salaf and Khalaf seemed more relevant particularly in dealing with ta'wil and tafwìd.

Dāwūd al-Fațānī’s Ward al-Zawāhir frequently reconciled between the different opinions depending on the authority of the naqli and 'aqli. His attempt of reconciling applied to the agreement points of the disputes, or looking at the predominant side (tarji $h$ ) of one another, or accepting both (or more) of them in different contexts of understanding or one of them is more specific and the other is more general, or perhaps one abrogates another. For instance, he clarified the consensus (ijmā) between Salaf and Khalaf in regard to ta'wil and tafwi $\bar{d}$ after explaining the differences and its justifications between them. In fact, his attempt to harmonize between the Salaf and Khalaf in regard to anthropomorphic verses but not to extent of the perennial polemic between both, as each party shares the same goal, i.e. ma 'rifat Allāh. He asserted:

Salaf and Khalaf are in consensus pertaining to the obligation of glorifying Him against any meaning that causes ambiguous (wahm) impossibility of the attributes of Allah (mustahill). They surrender to the reality of knowledge that needs clarification, and believe that all the revealed text came from Allah. Thus, the matter should be left to Him as He says: "And those who have knowledge say we believe."

The above statement clearly indicates that he observed the distinction and consensus as well as the reason that lies behind the difference due to different interpretations of the Qur'anic verses. However, this regard only relates to the independent religious interpretation (ijtihädiyyah) that allows differences among the scholars and not the fundamental

\footnotetext{
${ }^{1}$ Ibid., 66.

${ }^{2}$ Ibid., 67.
} 
principles in which consensus is mandatory.

As for the relevance of authority of the naqlī of the Qur'ān and Sunnah, his Ward al-Zawāhir eventually inclined to the Salaf's approach towards the priority of the naqli in approaching Islamic creed. This is due to his attitude that revelation is superior to intellect. $\mathrm{He}$ stated:

The definite truth (s $a w \bar{a} b)$ in God's creatures (including humans) is by following the way (maslak) of the Salaf in the creed and holding on to what Allah has revealed (of naqli ) and was brought by the Prophet without any long discussion and too detail but in trying to increase the devotion as it should be (i.e. $\operatorname{taq} w \bar{a}){ }^{1}$

In fact, the harmonization (tawfiq) of the Salaf and Khalaf approaches pertaining to the ta'will and tafwì had also existed in the Malay scholars works of jawi treatises. However, his merit was due to his detailed explanation with its application of harmonization dealing with the theological dispute compared to the other Malay scholars who merely indicates their acceptance of both concept of ta'wīl and tafwì without further application.

\section{The Integrated Argumentations}

Dāwūd al-Fatān̄̄'s Ward al-Zawāhir sometimes attempted to integrate between disputes regardless of the literal textual contradictions, but rather to interpret such differences in different ways by focusing on the agreement points among them. For instance, regarding the dispute of the Ash 'arite and Abū Manșūr al-Māturīdī on happiness, Ash'arite indicated that happiness is for those who escape punishment by death as a Muslim, as determined by God by pre-determined (azalī). ${ }^{2}$ Meanwhile al-Māturīdī indicated that happiness exists in worldly life and it could change because of wretched Muslims who commit apostasy ( $k u f r)$ and real Muslims who live in happiness. This is because he voluntarily chooses Islam as a way of life which guarantees happiness in both this

\footnotetext{
${ }^{1}$ Ibid., 429.

2‘Abd al-Qāhir ibn Ṭāhir al-Tamīmī al-Baghdādī, Ușūl al-Dīn, (Istanbul: Matba'at alDawlah, 1928), 53.
} 
world and the hereafter, there is no such pre-determination. ${ }^{1}$ Thus, Dāwūd al-Fațānī compromised such distinctions by looking at the agreement points of both, that is that happiness is attainable through death as a Muslim based on the interpretation of the authentic arguments in this regard. ${ }^{2}$

Dāwūd al-Fatānī sometimes employed the same proof from different points of view. In respect of expiation (kaffärah) of small sins, he demonstrated the usage of definite proof (adillat qat' 'iyyah) as well as indefinite ones (adillat zanniyyah) in dealing with mutakallimūn's interpretive approach versus muhaddithūn's literal approach. For that, he quoted:

The scholars' dispute on expiation of small sins is applicable through refraining from committing the great sin (al-kaba'ir) whether it is based on definite proof (adillat qat 'iyyah) as well as indefinite ones (adillat zanniyyah). In fact, they agree (ittifāq) that avoiding great sins would expiate the small ones. ${ }^{3}$

Dāwūd al-Fațānī justified the mutakallimūn's interpretitave understanding of textual revealed sources (naqlī) which indicates that Allah's Will is absolute on whether to expiate such sins or not. ${ }^{4}$ In

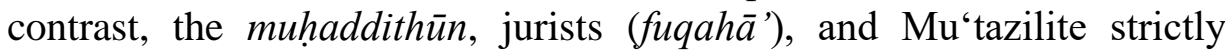
employ the literal text of naqli as a definite argument (qat ' $\bar{l}$ ) that avoiding the great sin would indicate expiation. In this regard, he was therefore inclined to the mutakallimūn's view but at the same time, he accepted the view of muhaddithün and others with the condition that the kaffärah is compliance with performing obligatory acts and avoiding great sins. Thus, there are no contradictions between the disputes except only in technical aspects with respect to Allah's Will (absolute free Will).

Dāwūd al-Fațān̄̄'s integration went even further as his integration is between not only the Salaf and Khalaf of the Ahl alSunnah, but also between the Ash'arite and Mu'tazilite that is in line with the Ahl al-Sunnah's thinking. In respect of the acts of servant ( $a f^{\prime} \bar{a} l$ $a l$ - $i b \bar{a} d)$, he indicated that the integration of the Ahl al-Sunnah

\footnotetext{
1 Muḥammad ibn Muḥammad al-Māturīdī,, Kitāb al-Tawḥìd, (al-Qāhirah: Dār alJāmi 'āt al-Mișriyyah, n.d), 325.

${ }^{2}$ Dāwūd al-Fațānī, Ward al-Zawāhir, 85-86.

${ }^{3}$ Ibid., 307.

${ }^{4}$ Ibid.
} 
(Ash'arite) and $\mathrm{Mu}$ 'tazilite was based on authentic arguments of the naqli that is in line with the Ahl al-Sunnah's doctrine. Regarding the agreement point between Ahl al-Sunnah and Mu'tazilite, he said:

The involuntary act of servants (af'āl idtiräriyyah) is like human body's reflection because of shock (which is happened without control) and is strictly subservient to Allah's Will (which is determined by His power and knowledge) as agreed among the scholars of the Ahl al-Sunnah and others. Thus, all deeds are under Allah's control (consent) even though such deeds are associated with human body such as "white" (colour) of the body (human) which actually is Allah's creation. This view has been agreed upon (muwāfaqah) between Ahl al-Sunnah and $\mathrm{Mu}$ 'tazilite which indicates that action comes from the human (body), not from colour (white) - even though Allah has created the body and colour but human determines his action- based on his own (voluntarily) choice... ${ }^{1}$

The above showed the agreement point between the Ahl al-Sunnah and $\mathrm{Mu}$ 'tazilite that one is answerable of his deeds based on his own free choice after rejecting Mu'tazilite doctrine of human's free actions that is not associated with Allah's Will. In fact, his rejection and integration is based on the justification of Qur'anic arguments of such matter. Thus, the authorized arguments based on naqli as well as 'aqli were among his consideration of dealing within the Ahl al-Sunnah or with the other parties, which eventually indicate his consistency with authority and harmonious dealing.

Dāwūd al-Fațānī's dealing with the conflict of two contradictory arguments was consistent as he was stick to to integrate both as complementary being in which one constitutes general (' $\bar{a} m$ ) and other specific ( $k h \bar{a} s \underline{s})$, as both are accepted and practiced in different contexts. For example, in respect of disbelief (kufr) and faith (imān) to the impossible attributes (mustahill) of God, he indicated:

Regarding belief ( $\bar{\imath} m \bar{a} n$ ) and disbelief (kufr) from religious (shar') and intellectual perspective (nazar 'aqlī), both revelation and intellect should be viewed from distinctive dimensions as the first (shar) remains in general and the other is specific. In

\footnotetext{
${ }^{1}$ Ibid., 82-83.
} 
respect of polytheism ( $k u f r$ ) for believers (mu'minūn), generally both shar' and 'aqli prohibit them to commit apostasy (kufr). In contrast, in regard of kufr for the unbelievers, the shar' does not order or prohibit, otherwise the logic ('aqlī) specifically prohibits $k u f r$ since Allah orders belief (ìmān) but He Wills otherwise. ${ }^{1}$

Regarding the possibility of $\bar{i} m \bar{a} n$ and $k u f r$, he attempted to integrate the religious view (shar) based on literal text (naqlī) and the interpretive understanding ( 'aqli $)$, however he inclined to specify it according to the logical interpretation of naqlī.$^{2}$ Likewise, his attempt to integrate different opinions regarding the fact of soul was based on broad and specific arguments. ${ }^{3}$

In fact, Dāwūd al-Fațānī's integration was consistent with his approaches on theology of authoritative propositions in harmonious dealing among disputes as reflected in his Ward al-Zawāhir. Thus, he shared same methodology with the majority of scholars (jumhīr) of the muhaddithūn, mutakallimūn, and fuqah $\bar{a}$ ' in dealing with dispute on theology. Apart from that, his Ward al-Zawāhir frequently stating "as stated in or according to naqli and 'aql$\vec{\imath}$ ' while presenting his arguments indicated his special treatment of his approaches on theology towards its goal (ma'rifat Allāh). As such, these contribute to affirm the Islamic creed as in Ward al-Zawāhir.

\section{The Abrogation (Mansūkh)}

Dāwūd al-Fațānī’s Ward al-Zawāhir described the abrogation (mansūkh) and its categories without detailed explanations especially pertaining to its application on theological issues. Otherwise, he sought to demonstrate the role of mansükh in dealing with disputable arguments concerning the usage of the Qur'anic verses and $a$ ha $\bar{a} d \bar{t} t h .{ }^{4}$

However, he indicated the theological purpose of abrogation (is to oppose the Jews and Christians who accuse that Islamic Law (Muhammadan's Law) does not abrogate the previous laws (sacred laws). The mansükh is prescribed from revealed sources (naqlī),

\footnotetext{
${ }^{1}$ Ibid. 78.

${ }^{2}$ Ibid.

${ }^{3}$ Ibid. 261.

${ }^{4}$ Ibid., 150-153.
} 
consensus (ijmā'), and intellect ('aqlī).

In describing divisions and types of mansūkh, Dāwūd al-Fațānī for instance, stated that the Sunnah abrogates another Sunnah which literally seems contradictory as in the case of visiting tombs based on the Hadìth, he said: "I have prohibited you from visiting tombs, and now you may be (allowed) to visit them." In this regard, he merely demonstrated an example of abrogation of Sunnah with Sunnah, but at least this becomes part of his harmonious approach in dealing with different arguments without any contradictions. In this regard, the proper interpretation is in line with the text, so it could be interpreted from various dimensions. ${ }^{1}$

In fact, his effort to be in line with the harmonization and integration approaches was consistent as he frequently presented the optimal use of arguments on theology of the naqli and 'aqli together based on its authority. For that, the popular words illustrating his attitude say: "It has been proven from naqli (revealed sources) and 'aqli (intellect)," if it involves both forms of the arguments and otherwise, he stated such a constraint.

\section{Conclusion}

Dāwūd al-Fațānī's attitude in dealing with the authority of naqlī and ' $a q l \bar{l}$ is significant and consistent in the sense of complementary manner. He signified the use of 'aqli to approach the Islamic creed and to get rid from blind imitation (taqlīd) to certitude (yaqīn) towards knowing God (ma'rifat Allāh) within its limitation that indicates naqli is to be superior to 'aqlī. For that, he frequently asserted the superiority of naqli over 'aqli throughout his writings, particularly on matters that could not be proven or it has become irrelevant through intellect and senses such as unseen matters (al-ghaybiyyāt). As such, the 'aqli approaches must be in line with principles of shar' to avoid the infiltration of foreign elements and therefore become capable of eliminating blind imitation (taqlīd) towards ma 'rifat Allāh.

1 Dāwūd al-Fațānī divided the mansūkh into three categories which are: (1) the abrogation of law (hukm) only, (2) the verse (lafz) only, and (3) law and verse (hukm and lafz) altogether. Meanwhile there are three types of mansükh which consist of (1) the abrogation of the Qur'ān with the Qur'ān, (2) the Qur'ān with the Sunnah, and (3) the Sunnah with the Sunnah. See Dāwūd al-Fatān̄̄, Ward al-Zawāhir, 151.

${ }^{2}$ Ibid., 101. 
Thus, based on the authority, he sought to integrate and harmonize any theological distinctions by looking at the agreement points rather than distinctive ones particularly in dealing with the polemic of anthropomorphism (tashbihh) between the Salaf and Khalaf. His harmonization of the disputed arguments could be viewed from various angles that justify each other whether by the preference way (tarji $h)$, or integration between the general and specific arguments, or to reconcile the understanding of the arguments in different contexts. The same goes with respect to the abrogation (mansükh) discourse. This would indicate his treatment of the aqli approaches based on the authoritative arguments in his Ward al-Zawāhir is relevant and significant towards knowing God (ma 'rifat Allāh).

\section{References}

Abdullah, Wan Mohd Shaghir bin, "Pengarang manuskrip kitab di Alam Melayu: suatu tinjauan awal," Jurnal Filologi Melayu, vol. 3 (1994).

Al-'Asqalān̄̄ , Ibn Hajar Aḥmad ibn 'Alī ibn Muhammad, al-Nukat 'alā nuzhat alnazar fì tawḍ̄h nukhbat al-fikar, (al-Riyāḍ: Dār Ibn Jawzī, 2003).

Al-Ash'arī, Abū al-Hasan. al-Luma', (Bayrūt: Dār al-Kutub al-'Ilmiyyah, 2000).

al-Baghdādī, 'Abd al-Qāhir ibn Țāhir al-Tamīmī Ușūl al-Dīn, (Istanbul: Matba'at alDawlah, 1928), 53.

Al-Fațānī, Dāwūd bin 'Abd Allāh, Ward al-Zawāhir li ḥall alfāz 'Iqd al-Jawāhir ('ilm al-Tawhīd Ahl al-Sunnah wa al-Jamā'ah), edited by Wan Mohd Shaghir bin Abdullah, (Kuala Lumpur: Khazānat al-Fațāniyyah, 2000).

Al-Ghazālī , Abū Ḥāmid Muḥammad, al-Munqidh min al-ḍalāl. (Dimashq: Dār alHikmah, 1994).

Al-Khaṭīb, Muḥammad 'Ajāj, Ușūl al-Hadìth, (Bayrūt: Dār al-Fikr, 1981),

Al-Māturīdī, Muḥammad ibn Muḥammad. Kitāb al-Tawhīd, (al-Qāhirah: Dār alJāmi āat al-Mișriyyah, n.d).

Al-Qāsimī Jamāl al-Dīn Ibn Muḥammad Sa'īd, Qawā id al-taḥdīth min funūn muștalah al-ḩadīth, (Bayrūt: Dār al-Kutub al-'Ilmiyyah, 1979).

Al-Suyūṭị, Jalāl al-Dīn 'Abd al-Raḥmān ibn Abū Bakr, Tadrīb al-Rāwī fì sharh Taqrīb al-Nawawī, (al-Madīnah: Maktabat al-'Ilmiyyah, 1972).

Bradley, Francis R. "Syeikh Daud bin Abdullah al-Fațān̄̄'s writings contained in the National Library of Malaysia," Jurnal Filologi Melayu, vol. 15 (2007).

Haji Abdullah, Abdul Rahman bin, Pemikiran umat Islam di Nusantara, (Kuala Lumpur: Dean Bahasa dan Pustaka, 1990).

Makdisi, George "Ash'arī and the Ash'arites in Islamic Religious History," in Islamic philosophy and theology, edited by Ian Richard Netton, (New York: Routledge, 2007). 